NBER WORKING PAPER SERIES

\title{
CORRUPTION AND COMPOSITION OF FOREIGN DIRECT INVESTMENT: \\ FIRM-LEVEL EVIDENCE
}

\author{
Beata K. Smarzynska \\ Shang-Jin Wei \\ Working Paper 7969 \\ http://www.nber.org/papers/w7969

\section{NATIONAL BUREAU OF ECONOMIC RESEARCH 1050 Massachusetts Avenue} \\ Cambridge, MA 02138 \\ October 2000
}

We wish to thank Hans Peter Lankes and Rafael Di Tella for help with some of the data and to Mary Hallward-Driemeier and Harry Grubert for useful suggestions. The views expressed in this paper are those of the authors and not necessarily those of the National Bureau of Economic Research, the World Bank, or any other organizations the authors are affiliated with. .

(C) 2000 by Beata K. Smarzynska and Shang-Jin Wei. All rights reserved. Short sections of text, not to exceed two paragraphs, may be quoted without explicit permission provided that full credit, including (C) notice, is given to the source. 
Corruption and Composition of Foreign Direct Investment: Firm-Level Evidence

Beata K. Smarzynska and Shang-Jin Wei

NBER Working Paper No. 7969

October 2000

JEL No. F23

\begin{abstract}
This paper studies the impact of corruption in a host country on foreign investor's preference for a joint venture versus a wholly-owned subsidiary. There is a basic trade-off in using local partners. On the one hand, corruption makes local bureaucracy less transparent and increases the value of using a local partner to cut through the bureaucratic maze. On the other hand, corruption decreases the effective protection of investor's intangible assets and lowers the probability that disputes between foreign and domestic partners will be adjudicated fairly, which reduces the value of having a local partner. The importance of protecting intangible assets increases with investor's technological sophistication, which tilts the preference away from joint ventures in a corrupt country. Empirical tests of the hypothesis on a firm-level data set show that corruption reduces inward FDI and shifts the ownership structure towards joint ventures. Technologically more advanced firms are found to be less likely to engage in joint ventures.
\end{abstract}

Beata K. Smarzynska

The World Bank

1818 H St, NW

Room H4-350

Washington DC, 20433

bsmarzynska@worldbank.org

\author{
Shang-Jin Wei \\ The Brookings Institution \\ 1775 Massachusetts Ave \\ Room 401 \\ Washington, DC 20036 \\ and NBER \\ Swei@brook.edu
}




\section{INTRODUCTION}

The issue of corruption has become a prominent item on the agenda of international institutions and national governments. ${ }^{1}$ The OECD Convention on Combating Bribery of Foreign Public Officials in International Business Transactions, which was signed in 1997 and went into effect in February 1999, criminalizes bribery of foreign officials by firms from member countries. Yet indices produced by organizations such as Transparency International suggest that corruption is still a widely spread phenomenon. While there exists evidence indicating that corruption has a negative impact on the magnitude of inward foreign direct investment inflows (Hines, 1995; and Wei, 2000a), little is known about how corruption affects the composition of these flows, which is the central focus of this paper.

There are two strands of literature related to this paper. The first one is the literature on foreign direct investment, too vast to be comprehensively referenced here (see Caves, 1982, and Froot, 1993, and the citations therein), which encompasses firm-level studies focusing on the choice of entry mode (for example, Kogut and Singh, 1988; Blomström and Zejan, 1991; Asiedu and Esfahani, 1998; Smarzynska, 2000). None of them, however, takes into account the effect of corruption on the decision to have a joint venture partner. A notable exception is a study by Henisz (2000) who examines the effect of corruption on FDI market entry and ownership mode for U.S. based multinational firms. Unfortunately, the estimated coefficients on corruption are mostly insignificant or with a wrong sign in the sense that corruption appears to be associated with more FDI. ${ }^{2}$ The second literature relevant for this paper analyzes the consequences or causes of corruption in a cross section of countries and includes Mauro (1995), Ades and Di Tella (1999), Kaufmann and Wei (1999) and others. Most of these papers do not deal with foreign direct investment. Wheeler and Mody (1992), Hines (1995), Wei (2000a and b) and Henisz (2000) are the only papers that we are aware of that examine the effect of corruption on foreign direct investment.

We believe that understanding the connection between corruption and FDI ownership composition is important for several reasons. First, understanding the determinants of FDI ownership composition is important in its own right. For example, many developing and transition economies are eager to attract foreign investors for the advanced technologies that

\footnotetext{
${ }^{1}$ See, for instance, "Transition" 7(9-10), September/October 1996.

${ }^{2}$ Henisz estimates separately the equations for market entry and ownership mode. In this paper, we estimate these two decisions jointly.
} 
they may bring. The technological content of a foreign investment varies with the ownership composition of the investment. Second, host country corruption ought to play a more significant role in theories and empirics of international capital flows than it does so far. Cross-country variation in corruption levels is as large as the variations in labor cost or corporate tax rate, two commonly emphasized determinants of international direct investment. Third, given that corruption is elusive to measure but important conceptually, it is useful to derive and test more nuanced predictions of the economic consequences of corruption, such as its effect on the composition of FDI. This could help increase our confidence that popularly used measures of corruption are indeed meaningful and informative.

In this paper, we study how a foreign investor's choice of entry mode may be affected by the extent of corruption in a host country. Corruption makes dealing with government officials, for example, to obtain export licenses and production permits, less transparent and more costly, particularly for foreign investors. In this case, having a local partner lowers the transaction cost (e.g., the cost of securing local permits). At the same time sharing ownership may lead to technology leakage. ${ }^{3}$ Both costs of local permits and losses from technology leakage are positively related to the extent of corruption in a host country. When corruption level is sufficiently high no investment will take place. When corruption is low enough so that investment can take place, the foreign investor with more sophisticated technology prefers a wholly-owned form, but, holding the technological level constant, the investor is more inclined to have a local partner in a more corrupt host country.

To see such an effect, we need firm-level data in a set of countries with enough variation in corruption levels. We test our hypotheses using a unique firm-level data from transition economies. ${ }^{4}$ We show that the probability of investment taking place is negatively related to the extent of corruption in a host country. Moreover, foreign investors with more sophisticated technologies in corrupt host countries are indeed more likely to retain full

\footnotetext{
${ }^{3}$ Smarzynska (2000) shows empirically that foreign investors with more sophisticated technologies are less likely to share ownership than investors possessing fewer intangible assets. She attributes this finding to concerns about knowledge dissipation that would lead to a greater loss in the case of investors with more sophisticated technologies.

4 Our data set is unique in the extent of its coverage. Previous studies on the choice of entry mode use data on FDI originating in one and less major source country (i.e., Sweden in the case of Blomström and Zejan, 1991, or the United States in the case of Henisz, 2000) or FDI entering a single host country (typically the United States as in the case of Kogut and Singh, 1988; Asiedu and Esfahani, 1998). Our data set covers investment projects undertaken in twenty-two economies by investors from all over the world.
} 
ownership of their projects than to engage in JVs. Our results are robust to using different measures of corruption.

Hines (1995) suggested that US multinationals behave differently than investors of other nationalities, namely, they tend to avoid joint ventures in corrupt countries. This behavior is likely to be a consequence of the Foreign Corrupt Practices Act of 1977 which stipulates penalties for executives of American companies whose employees or local partners engage in paying bribes. We find support for this view and show that US companies are more likely than investors from other countries to retain full ownership in corrupt countries, even though they are not less likely to undertake FDI in corrupt economies than firms from other source countries.

We organize the rest of the paper in the following way. Section II presents a minimalist model that highlights the effects of corruption and technological sophistication on the ownership structure of foreign investment. Section III discusses the empirical results. Section IV concludes.

\section{A MINIMALIST MODEL}

In this section, we present a simple model that will be used to motivate the subsequent empirical tests on corruption and the FDI entry mode. Let $q_{k}$ be the corruption level in host country $k$ defined over the interval $[0, \infty]$ and $t_{j}$ the level of technological sophistication of foreign investor $j$, also defined to be in the interval $[0, \infty]$. Note that where no confusion arises, we will drop the subscripts for simplicity.

The value of setting up a wholly owned firm to the foreign investor is:

$$
U(w o)=V_{w o}-C_{w o}\left(q_{k}\right)
$$

where $C_{w o}(q)$ is the cost of securing the local permits when not having a local partner. ${ }^{5} \mathrm{We}$ assume that this cost increases with the corruption level in the country:

$$
C^{\prime}{ }_{w o}(q)>0
$$

and

$$
C_{w o}(0)=0
$$

\footnotetext{
5 We use the label "local permits" to represent a variety of local inputs whose acquisition costs may rise as the local bureaucracy becomes less and less transparent.
} 
The value of setting up a joint venture to the foreign investor is:

$$
U(j v)=V_{j v}-L\left(t_{j}, q_{k}\right)-C_{j v}\left(q_{k}\right)
$$

where $L\left(t_{j}, q_{k}\right)$ is the technology leakage function and $C_{j v}(q)$ is the cost of securing the local permits to the foreign investor having a local partner. We assume that leakage is more likely in countries with a higher level of corruption and the cost of leakage increases with the sophistication of technology owned by the foreign investor. Thus,

$$
\begin{aligned}
& L_{t}>0, L_{q}>0, L_{t q}>0 \\
& L(0, q)=0
\end{aligned}
$$

We also assume that the cost of obtaining a local permit increases with corruption level.

$$
\begin{aligned}
& C^{\prime}{ }_{j v}(q)>0 \\
& C_{j v}(0)=0
\end{aligned}
$$

However, we assume further that as corruption rises, the cost of acquiring local permits increases faster for a foreign investor pursuing a wholly-owned firm than one with a local joint venture partner.

$$
C^{\prime}{ }_{j v}(q)<C^{\prime}{ }_{w o}(q)
$$

For simplicity, we choose specific linear functional forms for $L(t, q), C_{w o}(q)$ and $C_{j v}(q)$, that satisfy the conditions stated above, with an eye on yielding a parsimonious expression that can be estimated econometrically.

$$
\begin{aligned}
& \text { Let } C_{j v}=c q \\
& \begin{array}{l}
C_{w o}=(c+\theta) q \\
L(t, q)=\gamma t+\phi t q
\end{array}
\end{aligned}
$$

where c, $\theta, \gamma$ and $\phi$ are positive constants. With these assumptions, the value of a whollyowned investment project equals

$$
U(w o)=V_{w o}-(c+\theta) q
$$

And the value of a joint venture is

$$
U(j v)=V_{j v}-\gamma t-\phi t q-c q
$$

We will assume that $\mathrm{V}_{\mathrm{wo}} \geq \mathrm{V}_{\mathrm{JV}}$, as it seems plausible. However, our key conclusion regarding the effect of corruption on the composition of FDI does not depend on this assumption. 
The investor would consider setting up a wholly-owned project in a host country if $\mathrm{U}(\mathrm{wo})>0$, or $\mathrm{q}<\mathrm{V}_{\mathrm{wo}} /(\mathrm{c}+\theta)$. Likewise, she would consider engaging in a joint venture if $\mathrm{U}(\mathrm{jv})>0$, or $\mathrm{q}<\left(\mathrm{V}_{\mathrm{JV}}-\gamma \mathrm{t}\right) /(\mathrm{c}+\phi \mathrm{t})$.

The foreign investor would choose a wholly-owned project over a joint venture if and only if $U(w o)>U(j v)$ or

$$
V_{w o}-(c+\theta) q>V_{J V}-\gamma t-\phi t q-c q
$$

Rearranging the terms, we obtain

$$
t>\frac{\left(V_{J V}-V_{w o}\right)+\theta q}{\gamma+\phi q}
$$

The solution is best represented in Figure 1, where the investment decision is mapped out in a two-dimensional space along the level of corruption in the host country and the level of technological sophistication of the investing firm. When corruption level $q$ is sufficiently high, no foreign investment in any ownership form would take place. Conditional on foreign investment taking place, the foreign investor would prefer a wholly-owned form if its technology is sufficiently sophisticated. On the other hand, holding the level of technological sophistication constant, the higher the corruption (up to a limit), the more inclined the foreign investor is to set up a joint venture.

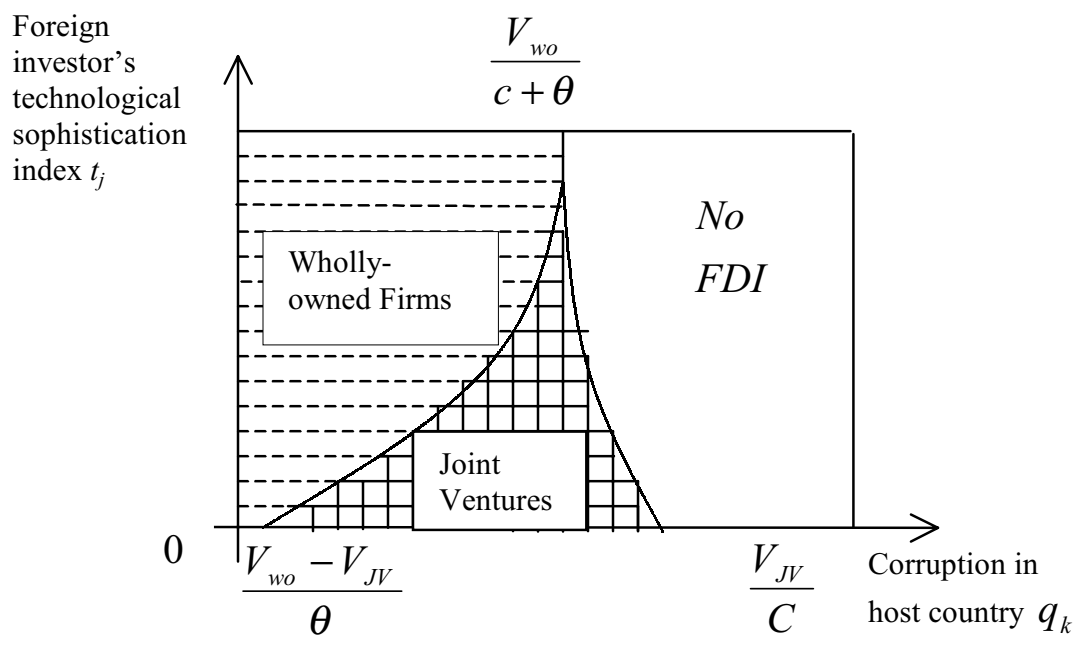

Figure 1: FDI Decision as a function of local corruption and firm's technology 


\section{EMPIRICAL EVIDENCE}

In this section, we report the statistical evidence on the connection between corruption and ownership structure of foreign direct investment. We describe the empirical work in three steps: (1) the economic specification, (2) some key variables (their measures and sources, with more details in a separate appendix), and (3) the regression results and their interpretations.

\section{Econometric Specification}

While using the simple theoretical model in the previous section to motivate our econometric specification, we also bring in additional control variables that the literature on foreign investment suggests are important. More specifically, we estimate a system consisting of two parts. The first part describes the investor's decision to enter a particular host country, $k$. The second part describes the decision on the choice between wholly-owned form versus joint venture, conditional on FDI taking place.

Let $F D I_{j k}$ be a dummy variable that takes the value of one if firm $j$ chooses to invest in host country $k$, and zero otherwise. We assume that this investment takes place if and only if a latent variable, $F D I^{*}{ }_{j k}$ is positive. The latent variable depends on a vector of factors including the level of corruption in host country $k$, denoted by $q_{k}$. In other words,

$$
\begin{aligned}
& \operatorname{FDI}_{j k}=1 \text { if } \operatorname{FDI}_{j k}^{*}>0 \\
& \operatorname{FDI}_{j k}=0 \text { otherwise } \\
& \text { where } \\
& \operatorname{FDI}_{j k}^{*}=x_{j k} \beta+\gamma q_{k}+\varepsilon_{k j}
\end{aligned}
$$

$q_{k}=$ corruption level in country $k, X_{j k}=$ vector of determinants of FDI* other than corruption, and $\beta$ (vector) and $\gamma$ are parameters. In subsequent discussion and in the regression tables, we label the last equation on $F D I^{*}$ as the "FDI decision equation."

Let $O W N E R S H I P_{j k}$ be a dummy variable that takes the value of one if the foreign investment by firm $j$ takes the wholly-owned form in host country $k$ (conditional on the investment taking place), and zero if the investment is a joint venture. Wholly-owned form occurs if and only if another latent variable, $O W N E R S H I P^{*} k$, is positive. 
In other words,

$$
\begin{array}{ll}
\text { OWNERSHIP }_{j k}=1 & \text { if OWNERSHIP } \\
j k & >0 \text { and FDI }{ }_{j \mathrm{jk}}>0 \\
\text { OWNERSHIP }_{j k}=0 & \text { if OWNERSHIP } \\
j k & \leq 0 \text { and FDI }{ }_{j \mathrm{k}}>0
\end{array}
$$

where

$\operatorname{OWNERSHIP}_{j k}^{*}=W_{j k} \theta+\delta_{1} q_{k}+\delta_{2} t_{j}+v_{k j}$

$t_{j}$ is an index of technological sophistication for firm $j, W$ is a vector of determinants of the ownership structure other than host country's corruption and foreign investor's technological sophistication, $\theta$ (vector), $\delta_{1}$ and $\delta_{2}$ are parameters to be estimated. In subsequent discussion and in the regression tables, we label the last equation on OWNERSHIP* as the "ownership decision equation."

Assuming that $(\varepsilon, v)$ are i.i.d normal variables with zero means and correlation coefficient of $\rho$, we estimate these equations (probit with sample selection) simultaneously by maximum likelihood. The number of observations in the FDI decision equation is equal to the number of firms in the sample, multiplied by the number of destination countries in the sample. In the ownership decision equation, the number of observations is equal to the total number of FDI projects in the sample. The latter number is smaller than the former because not all firms invest in all countries.

In terms of the parameterization described above, the central hypotheses that we seek to test are the following:

(a) Corruption discourages foreign direct investment, i.e., $\gamma<0$, in the FDI decision equation;

(b) Conditional on FDI taking place and holding constant the technological level of the foreign investor, corruption encourages the joint venture form (or discourages the sole ownership), i.e., $\delta_{l}<0$, in the ownership decision equation;

And (c) conditional on FDI taking place, a more technologically advanced firm is more likely to adopt a wholly-owned form, i.e., $\delta_{2}>0$ in the ownership decision equation.

\section{$\underline{\text { Data }}$}

Our empirical work employs a unique firm-level data set based on a survey conducted by the European Bank for Reconstruction and Development. In January 1995, a brief questionnaire was sent out to all companies (about 9,500) listed in the Worldscope 
database. ${ }^{6}$ Responses were obtained from 1,405 firms that answered questions regarding their existing or planned FDI in Eastern Europe and the former Soviet Union. ${ }^{7} 381$ respondents had actually invested and further 70 firms planned to invest in the region. The distribution of projects across the host countries as well as the list of source countries is presented in Table 1.

The survey inquired about the form of the project: a joint venture with a local partner, acquisition or greenfield. For the purposes of this study, we treat all projects not associated with JVs as wholly owned. The questionnaire did not ask for the exact ownership shares between foreign and local partners for joint ventures, nor the timing nor the size of the investment, which are unfortunate for us. Since inflows of FDI were negligible prior to 1989 , the investments covered in our sample took place (or were planed to take place) between 1989 and $1995 .{ }^{8}$ Table 1 presents the distribution of investment projects across host countries.

A key regressor is host country's corruption level. Corruption, by its very nature, is difficult to get measure precisely. There are a few measures available "on the market," all of which are subjective perceptions ${ }^{9}$. There are several types of such indexes. The first is based on surveys of individual "experts" (typically every country is rated by one expert). Popular examples of this type include the Business International (BI) Index used in Mauro (1995), Wei (1997 and 2000a) and others, and International Country Risk Group (ICRG) index used by, for example, Ades and Di Tella (1999) and Wei (2000a). The second type is based on surveys of firms. Typically multiple firms per country are surveyed, and the average answer for each country is used as the value of corruption index for that country. Relative to the first type, this type of indexes reduces the impact of the idiosyncratic errors of individual respondents. Most popular indexes of this type include the Global Competitiveness Report (GCR) index by the World Economic Forum and the World Development Report (WDR) index by the World Bank. Both GCR and WDR indexes were

\footnotetext{
${ }^{6}$ Worldscope is a commercial database that provides detailed financial statements, business descriptions, and historical pricing information on thousands of public companies located in more than fifty countries.

${ }^{7} 117$ of the survey respondents were chosen for in-depth interviews whose results are discussed in Lankes and Venables (1996).

8 "Several CEECs had already allowed minority foreign participation in joint ventures in the 1970s and 1980s, but this opportunity was not attractive enough to foreign investors. Except for a few showpieces, foreign investment started to flow only after the transformation to market economy had been launched" (Hunya, 1997, p. 286).

${ }^{9}$ See Wei (1999) for a discussion of the various corruption indexes.
} 
used in Kaufmann and Wei (1999). The third type is to pool together information from several existing indexes by averaging or other statistical extraction methods. The most widely known index of this type is the one compiled by the Transparency International (TI), an international non-governmental organization dedicated to fighting corruption. ${ }^{10}$ Unfortunately, many of these indexes such as the BI, GCR and ICRG indexes, do not cover enough transition economies to be useful for our examination.

In this paper, we use three corruption indexes that have adequate coverage of the transition economies. The first one is the WDR index, which is based on a survey undertaken in 1996 by the World Bank in preparation of the World Development Report 1997. The survey covered 3,866 firms in 73 countries. The rating is based on the response to Question 14 which asked: "Is it common for firms in my line of business to have to pay some irregular, 'additional' payments to get things done?" The respondents were asked to rate corruption on a 1 to 6 scale with 1 denoting "always" and 6 "never." To facilitate interpretation of the results we re-scaled the variable in the following way: re-scaled WDR index $=7$ - original WDR index. Thus, a higher value corresponds to a higher level of corruption.

The second measure is the 1999 Transparency International Corruption Perception Index (TI index for short) which pools information from ten different surveys of business executives, risk analysts and the general public. The original index ranges between 10 (highly clean) and 0 (highly corrupt). Again we re-scale the index so that a higher value corresponds to a higher level of corruption.

There is, however, a regrettable mismatch in timing between the WDR and TI corruption measures (1996 and 1999, respectively) and our FDI figures (1995). We note though that the relative rankings of corruption levels across countries are unlikely to change very much in a five year span. For example, the International Country Risk Group (ICRG) corruption index covers eight countries in our sample. The Spearman rank correlation coefficients for these countries are 0.98 between the 1994 and 1996 values, and 0.94 between the 1994 and 1998 values, respectively. Hence, as far as these countries are concerned, the relative rankings are fairly stable in the 1990s. Nonetheless, the mismatch is

\footnotetext{
${ }^{10}$ Kaufmann, Kraay and Zoido-Lobaton (1999) constructed their own index by pooling information from existing indexes using an unobserved component method.
} 
a shortcoming that we need to keep in mind when interpreting the results with WDR and TI indexes.

The third measure of corruption is based on the information obtained by Peter Neumann (1994), a journalist at a German business publication Impulse, from people with business experience in each host country, mainly German exporters. He interviewed on average ten individuals (or minimum three) per country with a guarantee of strict confidentiality. The measure indicates the proportion of the transactions that involved corrupt payments. This measure has two advantages, it is a "harder" and "more objective" than the other indexes used and it is based on the information collected in 1994 which was just a year before our FDI data was obtained. ${ }^{11}$

Note that our estimation would produce a negative sign on the corruption variable if corruption per se was not affecting the choice of entry mode but its level was positively correlated with the restrictions on the extent of foreign ownership. To the best of our knowledge, however, in none of the countries in the sample there exists legislation specifically forbidding full ownership by foreign investors. For instance, in the USSR a presidential decree issued as early as October 1990 allowed foreign wholly owned companies to be established in the form of branches or subsidiaries. The decree also created the legal basis for foreign investors to buy out existing Soviet enterprises as these were privatized (McMillan 1996, p. 50). In Hungary, Act XXIV of 1988 on the Investment of Foreigners in Hungary allowed non-Hungarian companies to own equity up to $100 \%$ (WTO, 1998). In Poland, the 1988 Law on Economic Activity with the Participation of Foreign Parties permitted 100 per cent foreign equity participation (GATT, 1992).

In many transition economies, however, FDI in sectors such as production of military equipment and extraction of natural resources has been subject to restrictions on the extent of foreign ownership. ${ }^{12}$ Therefore, we exclude firms in the coal, gas and oil industry from our sample. Since service sectors tend to be more restricted than manufacturing, we focus on firms in manufacturing sectors only.

Another crucial variable in our regressions is a measure of investor's technological sophistication. We use the ratio of firm R\&D intensity to the industry average, as suggested

\footnotetext{
${ }^{11}$ Neumann's index was used by Ades and Di Tella (1997).

${ }^{12}$ See Dunning and Rojec (1993) for a description.
} 
by Smarzynska (2000). ${ }^{13} \mathrm{We}$ also include industry level R\&D intensity. In addition to technology leakage, foreign investors may be concerned about dissipation of other intangible assets, for instance, marketing techniques. Thus, we also control for industry advertising intensity and investor's sophistication in marketing techniques. The latter is proxied by investor's advertising intensity relative to the industry mean. ${ }^{14}$ All of these variables, with the exception of industry advertising intensity, were found by Smarzynska to be positively related to the probability of full ownership.

Additionally, we control for firm size, production diversification and the distance between home and host countries. Blomström and Zejan (1991) suggested that larger firms are more likely to take higher risks and thus more often choose full ownership. Their empirical results, however, led to the opposite conclusion. Stopford and Wells (1972) pointed out that more diversified firms may be more tolerant towards minority ownership and thus more likely to engage in JVs. Meyer (1998) has confirmed this prediction. Finally, we include a measure of the distance between investor's home country and the investment destination. This can be a proxy for the degree of information asymmetry, "cultural" distance, or unfamiliarity with legal/institutional environment. As Kogut and Singh (1988) have shown, cultural distance is positively related to the probability of a JV which suggests that a local partner is more useful in less familiar environment.

The investment equation includes several other regressors such as a host country's GDP, GDP per capita, distance between investor's country and the host as well as a measure of openness to trade and corporate tax rates in the host country. We expect to find that the probability of investment is positively related to the market size (GDP) and purchasing power of local consumers (GDP per capita) and negatively correlated with distance and tax rates. ${ }^{15}$ Additionally, we control for production diversification as it has been argued that less

\footnotetext{
${ }^{13} \mathrm{R} \& \mathrm{D}$ intensity is defined as the ratio of $\mathrm{R} \& \mathrm{D}$ expenditure to net sales. The figures for R\&D intensity and other firm specific variables come from the Worldscope database. See Appendix I for more details.

${ }^{14}$ There is also another reason why firms investing heavily in advertising may want to seek full ownership. A $\mathrm{JV}$ partner may have a strong incentive to free ride on the reputation of a foreign partner by debasing the quality of the product carrying the foreign trademark. In such a case, the local partner appropriates the full benefits of debasement while bearing only a small fraction of the costs (Caves, 1982).

${ }^{15}$ Because of data constraints, we use statutory tax rates even though effective tax rates might be more appropriate. However, Wei's (1999) findings indicate that substituting the former tax rates with the latter has a negligible effect on the results.
} 
diversified firms are more likely to be forced by competitive pressures in their home countries to search for new markets. ${ }^{16}$

All variables are described in more detail in Appendix I. Summary statistics are listed in Table 1A in Appendix II.

\section{$\underline{\text { Statistical Results }}$}

Table 2 presents the estimation results with each column corresponding to a regression employing a different corruption measure. The top panel describes the FDI decision equation. We find that foreign investors that are large and have a less diversified production structure are more likely to invest in transition economies. They are attracted to countries with large markets and low tax rates. To the extent that the GDP per capita captures labor costs, foreign investors appear to be attracted to economies with cheap labor. Additionally, distance between investor's country and the host has a negative impact on the probability of FDI. While the signs of the variables described above are correct, they are not always significant in all regressions.

More essential for the current paper, we find that more corruption in a host country is associated with a lower probability of investment. All three indexes of corruption bear negative coefficients that are significant at the one percent level.

In the lower panel of the table, the results on the ownership decision are reported. We find that the coefficient on corruption is negative and statistically significant in all three regressions indicating that corruption encourages foreign investor to form a joint venture with a local partner, which is consistent with our hypothesis. The coefficients on measures of the foreign investor's level of technological (and marketing) sophistication are positive and (mostly) significant, indicating that firms with better technology are more reluctant to use local partners, which is also consistent with our hypothesis.

In the FDI decision equations (top panel of Table 2), the interaction terms between corruption and technological sophistication do not appear to be statistically significant. Interactions with marketing sophistication proxies bear positive and significant coefficients. This result suggests that marketing know-how does not affect investors' decisions in the same way as technological sophistication.

${ }^{16}$ See Markusen (1995) for a survey of FDI determinants. 
In regressions that are not reported here, we have also experimented with including the interactive terms between firms' technological sophistication and host country corruption in the ownership decision equations. If we do not include the measures of technological level by themselves, the coefficients on the interactive terms are positive and statistically significant. Corruption variable continues to have a negative and statistically significant coefficient in the ownership decision equation. This result can be consistent with the following hypothesis: foreign investors are generally more inclined to form joint ventures in a corrupt country, but their interest in joint ventures decreases with their level of technological sophistication because of the concern that intellectual property rights protection becomes more problematic in a more corrupt country.

On the other hand, if both the interactive terms and the technology variables by themselves are included in the ownership decision equations, both sets of coefficients become statistically insignificant. This could be due to a multicollinearity problem. Therefore, we are not able to say anything definitive about the interactive term between corruption and technological sophistication.

As mentioned at the beginning of the paper, Hines (1995) suggests that US multinationals are more likely to avoid joint ventures in corrupt countries than investors of other nationalities. To test this hypothesis, we include in both equations a dummy variable for US investors and an interaction between the dummy and corruption level. The results are presented in Table 3. We find no evidence that American firms invest less in corrupt countries, which is consistent with the results of Wei (2000a). We find, however, some evidence of US companies being indeed more averse to joint ventures in more corrupt host countries (or more likely to set up wholly-owned firms). The interaction between the US dummy and the corruption measure bears a positive and significant coefficient in two out of three regressions. Under the US Foreign Corrupt Practices Act of 1977, American investors are legally liable (and thus can be fined or jailed) if their local joint venture partners pay bribes, and this might induced them to engage less in joint ventures. 


\section{CONCLUSIONS}

This paper studies how a foreign investor's choice of the entry mode is affected by both the investor's technological sophistication and the extent of corruption in a host country. Corruption makes local bureaucracy less transparent and hence increases the value of a local joint venture partner to a foreign investor. On the other hand, foreign investors with sophisticated technology may worry about leakage of technological know-how by joint venture partners and are thus less inclined to form a joint venture.

We test these hypotheses using a firm-level data set on FDI in Eastern Europe and the Former Soviet Union in the 1990s. The data are broadly consistent with our hypotheses. In addition, we find that, other things equal, American investors are somewhat more reluctant to form joint ventures in more corrupt countries, possibly because of the U.S. Foreign Corrupt Practices Act of 1977.

For joint venture firms, our data set does not have information on the exact ownership shares between foreign and local partners. It may be useful to work out the effect of corruption on majority- versus minority-owned joint ventures and test it with some more refined data in the future. 


\section{REFERENCES}

Ades, Alberto, and Rafael Di Tella, 1997, "National Champions and Corruption: Some Unpleasant Interventionist Arithmetic,” Economic Journal. 107: 1023-1042.

Ades, Alberto, and Rafael Di Tella, 1999, "Rents, Competition, and Corruption," American Economic Review. 89(4): 982-993.

Asiedu, Elizabeth and Hadi Salehi Esfahani, 1998, "Ownership Structure in Foreign Direct Investment Projects” CIBER Working Paper No. 98-108.

Blomström, Magnus and Mario Zejan, 1991, "Why Do Multinational Firms Seek Out Joint Ventures?” Journal of International Development. 3(1): 53-63.

Caves, R., 1982, Multinational Enterprise and Economic Analysis. Cambridge University Press: New York.

Dunning, John H and Matija Rojec, 1993, Foreign Privatization in Central \& Eastern Europe. CEEPN: Ljubljana, Slovenia.

Froot, Kenneth, 1993, Foreign Direct Investment, Chicago: University of Chicago Press.

GATT, 1992, Trade Policy Review: Poland. Geneva. Vol. 1.

Havlik, Peter, 1996, "Exchange rates, competitiveness and labour costs in Central and Eastern Europe," WIIW Research Report No. 231 (WIIW, Vienna).

Henisz, Witold J. 2000. "The Institutional Environment for Multinational Investment," Journal of Law, Economics and Organization. 16(2): 334-364.

Hines, James R. Jr., 1995, "Forbidden Payment: Foreign Bribery and American Business After 1977” NBER Working Paper 5266.

Hunya, Gabor, 1997, Large privatisation, restructuring and foreign direct investment in: Salvatore Zecchini, ed., Lessons from the economic transition. Central and Eastern Europe in the 1990s (Kluwer Academic Publishers, Dordrecht, Boston and London): 275-300.

Kaufmann, Daniel, Aart Kraay, and Pablo Zoido-Lobaton, 1999, "Aggregating Governance Indicators.” World Bank working paper.

Kaufmann, Daniel, and Shang-Jin Wei, 1999, "Does 'Grease Payment' Speed Up the Wheels of Commerce?" NBER Working Paper 7093, April. Also released as a World Bank Policy Research Working Paper 2254.

Kogut, Bruce and Harbir Singh, 1988, "The Effect of National Culture on the Choice of Entry Mode," Journal of International Business Studies. 19: 411-432.

Lankes, Hans-Peter and Anthony J. Venables, 1996, "Foreign direct investment in economic transition: The changing pattern of investments," Economics of Transition. 4: 331-347.

Markusen, James R., 1995, The boundaries of multinational enterprises and the theory of international trade, Journal of Economic Perspectives. 9: 169-189.

Mauro, Paolo, 1995, “Corruption and Growth," Quarterly Journal of Economics, 110: 681-712. 
McMillan, Carl H., 1996, "Foreign Investment in Russia: Soviet Legacies and Post-Soviet Prospects" in Patrick Artisien-Maksimenko and Yuri Adjubei, eds. Foreign Investment in Russia and Other Soviet Successor States. St. Martin's Press, Inc.: New York: 41-72.

Meyer, Klaus E., 1998, Direct Investment in Economies in Transition. Edward Elgar: Cheltenham, UK and Northampton, MA.

Neumann, P. 1994. "Bose: fast alle bestechen," Impulse, Hamburg: Gruner + Jahr AG\&Co, pp.12-16.

Pearce, E.A. and C.G. Smith, 1984, The World Weather Guide, London: Hutchinson.

Rudloff, Willy, 1981, World Climates, with tables of climatic data and practical suggestions, Stuffgart: Wissenschaftliche Verlagsgesellschaft.

Smarzynska, Beata K., 2000, "Technology Transfer and Foreign Investors' Choice of Entry Mode" The World Bank Policy Research Working Paper No. 2314.

Stopford, John M. and Louis T. Wells, Jr., 1972, Managing the Multinational Enterprise. Basic Books, Inc.: New York.

Wei, Shang-Jin, 1997, "Why is Corruption So Much More Taxing Than Taxes? Arbitrariness Kills, “National Bureau of Economic Research Working Paper 6255, November.

Wei, Shang-Jin, 1998, "Corruption and Economic Development in Asia," in Integrity in Governance in Asia, edited by the United Nations Development Program, New York: UNDP.

Wei, Shang-Jin, 1999, "Does Corruption Relieve the Burden of Taxes and Capital Controls for International Investors?" The World Bank Policy Research Working Paper No. 2209.

Wei, Shang-Jin, 2000a, "How Taxing Is Corruption on International Investors?" Review of Economics and Statistics. 82 (1): 1-11.

Wei, Shang-Jin, 2000b, "Local Corruption and Global Capital Flows," Brookings Papers on Economic Activity. Forthcoming.

Wheeler, David and Ashoka Mody, 1992, "International Investment Location Decisions: The Case of US Firms,” Journal of International Economics 33:57-76.

WTO, 1998, Trade Policy Review: Hungary. Geneva. 


\section{APPENDIX I}

Firm specific variables used in the empirical analysis come from Worldscope which is a commercial database providing detailed financial statements, business descriptions, and historical pricing information on thousands of public companies located in more than fifty countries. They pertain to 1993 or the closest year for which the information was available and refer to worldwide operations of each firm. Below we present a more detailed description of the variables.

$>$ Industry $R \& D$ intensity: measured by $\mathrm{R} \& \mathrm{D}$ expenditure as a percentage of net sales. To find the industry averages we used figures for all firms listed in Worldscope in a given industry. The industry averages have been calculated at the three digit SIC industry classification ${ }^{17}$

$>$ Relative $R \& D$ intensity: measured by the ratio of a firm's R\&D intensity to the industry average ${ }^{18}$

$>$ Industry advertising intensity: measured by Sales, General and Administrative expenditure divided by net sales. This variable is a standard proxy for advertising intensity used in the literature

$>$ Relative advertising intensity: measured by the ratio of a firm's advertising intensity to the industry average

$>$ Firm size: measured by a firm's sales in millions of US dollars

$>$ Diversification: measured by the number of four digit SIC codes describing a firm's activities

$>$ GDP and GDP per capita: data for 1993. Source: EBRD (1994)

> Corruption WDR: WDR rating is based on the response to question 14 which asked:

"Is it common for firms in my line of business to have to pay some irregular, "additional" payments to get things done?" The respondents were asked to rate corruption on a 1 to 6 scale with 1 denoting "always" and 6 "never." To facilitate interpretation of the results we rescaled the variable in the following way: rescaled

\footnotetext{
${ }^{17}$ When calculating industry averages, we have removed two outliers from the drug sector and one from communications equipment industry. These firms reported R\&D intensities equal to 16598,1815 and 2560 , respectively. All three firms reported sales below $\$ 500,000$ thus they are likely to be start up companies. Note that the conclusions of the paper are remain unchanged even if this correction is not performed.
} 
WDR $=7$ - original WDR. Thus, higher values correspond to a higher level of corruption

> Corruption TI: Transparency International Corruption Perceptions Index relates to perceptions of the degree of corruption as seen by business people, risk analysts and the general public. It ranges between 10 (highly clean) and 0 (highly corrupt). Again we rescaled the index so that higher values correspond to a higher level of corruption. Rescaled TI index $=11-$ original TI index

$>$ Neumann Corruption Index: The proportion of deals in a host country that involved corrupt payments. Based on information collected by Neumann (1994). The index value of 1 corresponds to $10 \%$ of transactions involving corrupt payments, 2 to $20 \%$, etc.

> Distance: logarithm of distance in kilometers between the capital cities. The primary source is Rudloff (1981), supplemented by Pearce and Smith (1984). In the case of following countries the average distance from the main cities was used: Argentina (Buenos Aires, Cordoba, Rosario), Australia (Canberra, Sydney, Melbourne), Canada (Toronto, Vancouver, Montreal), Russia (Moscow, St. Petersburg, Nizhni Novogorod). The data for Nizhni Novogorod is from http://www.unn.runnet.ru/nn/whereis.htm. For the United States Kansas City, Missouri was used, for Netherlands De Bilt, Slovakia Poprad, Switzerland Zurich. Distances between Taiwan and other countries are from Shang-jin Wei's NBER web site: www.nber.org/ wei.

$>$ Openness: the sum of exports and imports as a share of GDP. The average value for 1991-95 has been used. Source: The World Bank.

$>$ Corporate tax rate: in percentages; if several rates apply, the highest one was used. Source: PriceWaterhousePaineWebber.

Distance, GDP, GDP per capita and firm size are used in the log form.

\footnotetext{
${ }^{18}$ If firm and industry level figures were both equal to zero, relative R\&D intensity took on the value of one.
} 
Table 1. Distribution of Projects by Host Country

\begin{tabular}{|c|c|c|c|}
\hline Host country & $\begin{array}{c}\text { No of JV projects in } \\
\text { the sample }\end{array}$ & $\begin{array}{l}\text { No. of wholly owned } \\
\text { projects in the sample }\end{array}$ & $\begin{array}{c}\text { Total no. of projects in } \\
\text { the sample } \\
\end{array}$ \\
\hline Albania & 3 & 1 & 4 \\
\hline Azerbaijan & 1 & 1 & 2 \\
\hline Belarus & 5 & 3 & 8 \\
\hline Bulgaria & 16 & 13 & 29 \\
\hline Croatia & 7 & 4 & 11 \\
\hline Czech & 55 & 53 & 108 \\
\hline Estonia & 16 & 8 & 24 \\
\hline FYR Macedonia & 2 & 1 & 3 \\
\hline Georgia & 4 & 2 & 6 \\
\hline Hungary & 50 & 48 & 98 \\
\hline Kazakhstan & 10 & 6 & 16 \\
\hline Latvia & 13 & 6 & 19 \\
\hline Lithuania & 8 & 5 & 13 \\
\hline Moldova & 2 & 0 & 2 \\
\hline Poland & 84 & 51 & 135 \\
\hline Romania & 21 & 12 & 33 \\
\hline Russia & 83 & 31 & 114 \\
\hline Slovakia & 26 & 19 & 45 \\
\hline Slovenia & 13 & 5 & 18 \\
\hline Turkmenistan & 1 & 0 & 1 \\
\hline Ukraine & 20 & 5 & 25 \\
\hline Uzbekistan & 5 & 1 & 6 \\
\hline TOTAL & 445 & 275 & 720 \\
\hline
\end{tabular}

Source countries (listed in the decreasing order of importance in the sample): Germany, United Kingdom, France, United States, Finland, Sweden, Switzerland, Netherlands, Denmark, Norway, Belgium, Australia, Japan, Austria, Portugal, Canada, Greece, Italy, Ireland, Brazil, Spain, Singapore, Malaysia, South Africa and South Korea. 


\section{TABle 2. CORRUPTION AND OWNERSHIP STRUCTURE OF FDI}

\begin{tabular}{|c|c|c|c|}
\hline & WDR 1997 & TI 1999 & Neumann Index \\
\hline \multicolumn{4}{|l|}{ FDI DECISION EQUATION } \\
\hline Constant & $\begin{array}{c}-4.0230 * * * \\
(0.6045)\end{array}$ & $\begin{array}{c}-2.4545 * * * \\
(0.7411)\end{array}$ & $\begin{array}{c}-4.1324 * * * \\
(0.5188)\end{array}$ \\
\hline Firm Size & $\begin{array}{c}0.2266 * * * \\
(0.0199)\end{array}$ & $\begin{array}{c}0.2196 * * * \\
(0.0186)\end{array}$ & $\begin{array}{c}0.2176 * * * \\
(0.0184)\end{array}$ \\
\hline Production Diversification & $\begin{array}{c}-0.0360 * * \\
(0.0182)\end{array}$ & $\begin{array}{c}-0.0435 * * \\
(0.0171)\end{array}$ & $\begin{array}{c}-0.0472 * * * \\
(0.0169)\end{array}$ \\
\hline Total GDP & $\begin{array}{c}0.4014 * * * \\
(0.0432)\end{array}$ & $\begin{array}{c}0.4855 * * * \\
(0.0449)\end{array}$ & $\begin{array}{c}0.4683 * * * \\
(0.0599)\end{array}$ \\
\hline GDP per capita & $\begin{array}{l}-0.0272 \\
(0.0630)\end{array}$ & $\begin{array}{c}-0.2514 * * * \\
(0.0825)\end{array}$ & $\begin{array}{l}-0.1000 * \\
(0.0597)\end{array}$ \\
\hline Corruption & $\begin{array}{c}-0.3606 * * * \\
(0.0766)\end{array}$ & $\begin{array}{c}-0.2383 * * * \\
(0.0555)\end{array}$ & $\begin{array}{c}-0.1381 * * * \\
(0.0362)\end{array}$ \\
\hline Firm Tech Sophistication & 0.0082 & 0.0041 & 0.0064 \\
\hline * Corruption & $(0.0084)$ & $(0.0038)$ & $(0.0056)$ \\
\hline Industry Tech Sophistication & -0.0031 & -0.0013 & -0.0003 \\
\hline * Corruption & $(0.0034)$ & $(0.0016)$ & $(0.0023)$ \\
\hline $\begin{array}{l}\text { Firm Marketing Sophistication } \\
\text { * Corruption }\end{array}$ & $\begin{array}{c}0.0573 * * * \\
(0.0187)\end{array}$ & $\begin{array}{c}0.0245 * * * \\
(0.0084)\end{array}$ & $\begin{array}{c}0.0391 * * * \\
(0.0120)\end{array}$ \\
\hline $\begin{array}{l}\text { Industry Marketing Sophistication } \\
\text { * Corruption }\end{array}$ & $\begin{array}{c}0.0046 * * * \\
(0.0007)\end{array}$ & $\begin{array}{c}0.0021 * * * \\
(0.0003)\end{array}$ & $\begin{array}{c}0.0027 * * * \\
(0.0005)\end{array}$ \\
\hline Distance & $\begin{array}{c}-0.4673 * * * \\
(0.0363)\end{array}$ & $\begin{array}{c}-0.4634 * * * \\
(0.0339)\end{array}$ & $\begin{array}{c}-0.4794 * * * \\
(0.0329)\end{array}$ \\
\hline Tax rate & $\begin{array}{l}-0.0012 \\
(0.0059)\end{array}$ & $\begin{array}{l}-0.0084 \\
(0.0055)\end{array}$ & $\begin{array}{c}-0.0134 * * \\
(0.0062)\end{array}$ \\
\hline Openness & $\begin{array}{c}0.0029 \\
(0.0019) \\
\end{array}$ & $\begin{array}{c}0.0028 \\
(0.0018) \\
\end{array}$ & $\begin{array}{c}0.0030 \\
(0.0019) \\
\end{array}$ \\
\hline \multicolumn{4}{|c|}{ OWNERSHIP DECISION EQUATION } \\
\hline Constant & $\begin{array}{c}-2.7343 * * * \\
(0.9608)\end{array}$ & $\begin{array}{c}-2.3751 * * \\
(0.9761)\end{array}$ & $\begin{array}{c}-2.1311 * * \\
(1.0558)\end{array}$ \\
\hline Firm Size & $\begin{array}{c}0.1537 * * * \\
(0.0507)\end{array}$ & $\begin{array}{c}0.1359 * * * \\
(0.0504)\end{array}$ & $\begin{array}{c}0.0789 \\
(0.0605)\end{array}$ \\
\hline Production Diversification & $\begin{array}{c}-0.1113 * * * \\
(0.0421)\end{array}$ & $\begin{array}{c}-0.0968 * * \\
(0.0415)\end{array}$ & $\begin{array}{c}-0.0907 * * \\
(0.0417)\end{array}$ \\
\hline Firm Tech Sophistication & $\begin{array}{c}0.1922 * * * \\
(0.0674)\end{array}$ & $\begin{array}{c}0.2083 * * * \\
(0.0653)\end{array}$ & $\begin{array}{c}0.2010 * * * \\
(0.0633)\end{array}$ \\
\hline Industry Tech Sophistication & $\begin{array}{c}0.1290 * * * \\
(0.0301)\end{array}$ & $\begin{array}{c}0.1247 * * * \\
(0.0295)\end{array}$ & $\begin{array}{c}0.1280 * * * \\
(0.0303)\end{array}$ \\
\hline Firm Marketing Sophistication & $\begin{array}{c}0.6894 * * * \\
(0.1640)\end{array}$ & $\begin{array}{c}0.7411 * * * \\
(0.1612)\end{array}$ & $\begin{array}{c}0.6816 * * * \\
(0.1740)\end{array}$ \\
\hline Industry Marketing Sophistication & $\begin{array}{c}0.0035 \\
(0.0070)\end{array}$ & $\begin{array}{c}0.0062 \\
(0.0068)\end{array}$ & $\begin{array}{c}0.0014 \\
(0.0068)\end{array}$ \\
\hline Corruption & $\begin{array}{c}-0.2304 \% \\
(0.1337)\end{array}$ & $\begin{array}{c}-0.1746 * * \\
(0.0709)\end{array}$ & $\begin{array}{c}-0.1301 * * * \\
(0.0504)\end{array}$ \\
\hline Distance & $\begin{array}{l}-0.0314 \\
(0.0963)\end{array}$ & $\begin{array}{c}0.0045 \\
(0.0988)\end{array}$ & $\begin{array}{c}0.0902 \\
(0.1150) \\
\end{array}$ \\
\hline Rho $(1,2)$ & $\begin{array}{c}0.1624 \\
(0.1779)\end{array}$ & $\begin{array}{c}0.1075 \\
(0.1722)\end{array}$ & $\begin{array}{c}-0.2267 \\
(0.2360)\end{array}$ \\
\hline $\begin{array}{l}\text { No of obs Eq1 } \\
\text { No of obs Eq2 } \\
\text { Log L }\end{array}$ & $\begin{array}{c}5688 \\
345 \\
-1108.86\end{array}$ & $\begin{array}{c}6320 \\
367 \\
-1227.28\end{array}$ & $\begin{array}{c}6004 \\
365 \\
-1224.59\end{array}$ \\
\hline
\end{tabular}

Standard errors are listed in parentheses. $* * *, * *, *$ denotes significance at $1,5,10 \%$ level, respectively 


\section{TABLe 3. ARE US INVESTORS SPECIAL?}

\begin{tabular}{|c|c|c|c|}
\hline & WDR 1997 & TI 1999 & Neumann Index \\
\hline \multicolumn{4}{|l|}{ FDI DECISION EQUATION } \\
\hline Constant & $\begin{array}{c}-2.3928 * * * \\
(0.6569)\end{array}$ & $\begin{array}{l}-0.9274 \\
(0.7806)\end{array}$ & $\begin{array}{c}-2.0949 * * * \\
(0.5896)\end{array}$ \\
\hline Firm Size & $\begin{array}{c}0.2184 * * * \\
(0.0201)\end{array}$ & $\begin{array}{c}0.2105 * * * \\
(0.0187)\end{array}$ & $\begin{array}{c}0.2088 * * * \\
(0.0186)\end{array}$ \\
\hline Production Diversification & $\begin{array}{l}-0.0128 \\
(0.0189)\end{array}$ & $\begin{array}{l}-0.0229 \\
(0.0177)\end{array}$ & $\begin{array}{l}-0.0265 \\
(0.0175)\end{array}$ \\
\hline Total GDP & $\begin{array}{c}0.4077 * * * \\
(0.0447)\end{array}$ & $\begin{array}{c}0.4807 * * * \\
(0.0466)\end{array}$ & $\begin{array}{c}0.4715 * * * \\
(0.0615)\end{array}$ \\
\hline GDP per capita & $\begin{array}{l}-0.0398 \\
(0.0645)\end{array}$ & $\begin{array}{c}-0.2409 * * * \\
(0.0846)\end{array}$ & $\begin{array}{c}-0.1418 * * \\
(0.0617)\end{array}$ \\
\hline Corruption & $\begin{array}{c}-0.3409 * * * \\
(0.0852)\end{array}$ & $\begin{array}{c}-0.1926 * * * \\
(0.0582)\end{array}$ & $\begin{array}{c}-0.1226 * * * \\
(0.0380)\end{array}$ \\
\hline Firm Tech Sophistication & 0.0067 & 0.0034 & 0.0054 \\
\hline$*$ Corruption & $(0.0090)$ & $(0.0041)$ & $(0.0061)$ \\
\hline Industry Tech Sophistication & -0.0021 & -0.0010 & 0.0000 \\
\hline * Corruption & $(0.0035)$ & $(0.0016)$ & $(0.0024)$ \\
\hline $\begin{array}{l}\text { Firm Marketing Sophistication } \\
* \text { Corruption }\end{array}$ & $\begin{array}{c}0.0625 * * * \\
(0.0191)\end{array}$ & $\begin{array}{c}0.0266 * * * \\
(0.0086)\end{array}$ & $\begin{array}{c}0.0417 * * * \\
(0.0123)\end{array}$ \\
\hline $\begin{array}{l}\text { Industry Marketing Sophistication } \\
* \text { Corruption }\end{array}$ & $\begin{array}{c}0.0048 * * * \\
(0.0008)\end{array}$ & $\begin{array}{c}0.0022 * * * \\
(0.0003)\end{array}$ & $\begin{array}{c}0.0028 * * * \\
(0.0005)\end{array}$ \\
\hline Distance & $\begin{array}{c}-0.6906 * * * \\
(0.0536)\end{array}$ & $\begin{array}{c}-0.7111 * * * \\
(0.0515)\end{array}$ & $\begin{array}{c}-0.7322 * * * \\
(0.0514)\end{array}$ \\
\hline Tax rate & $\begin{array}{l}-0.0034 \\
(0.0061)\end{array}$ & $\begin{array}{c}-0.0110 * \\
(0.0057)\end{array}$ & $\begin{array}{c}-0.0136 * * \\
(0.0062)\end{array}$ \\
\hline Openness & $\begin{array}{c}0.0022 \\
(0.0020)\end{array}$ & $\begin{array}{c}0.0021 \\
(0.0018)\end{array}$ & $\begin{array}{c}0.0024 \\
(0.0020)\end{array}$ \\
\hline US firm & $\begin{array}{c}0.3282 \\
(0.4661)\end{array}$ & $\begin{array}{c}0.8893 \\
(0.5451)\end{array}$ & $\begin{array}{c}1.0279 * * * \\
(0.2406)\end{array}$ \\
\hline US firm * Corruption & $\begin{array}{c}0.1267 \\
(0.1277)\end{array}$ & $\begin{array}{l}-0.0103 \\
(0.0713)\end{array}$ & $\begin{array}{l}-0.0414 \\
(0.0422)\end{array}$ \\
\hline
\end{tabular}

The table continues on the next page. 


\section{TABLE 3 CONTINUED}

\begin{tabular}{|c|c|c|c|}
\hline & WDR 1997 & TI 1999 & Neumann Index \\
\hline \multicolumn{4}{|c|}{ OWNERSHIP DECISION EQUATION } \\
\hline \multirow[t]{2}{*}{ Constant } & -1.5741 & -1.2578 & -1.5004 \\
\hline & $(1.1040)$ & $(1.1064)$ & $(1.1023)$ \\
\hline \multirow[t]{2}{*}{ Firm Size } & $0.1422 * * *$ & $0.1300 * *$ & 0.0809 \\
\hline & $(0.0526)$ & $(0.0515)$ & $(0.0605)$ \\
\hline \multirow[t]{2}{*}{ Production Diversification } & $-0.0997 * *$ & $-0.0868 * *$ & $-0.0876 * *$ \\
\hline & $(0.0434)$ & $(0.0424)$ & $(0.0422)$ \\
\hline \multirow[t]{2}{*}{ Firm Tech Sophistication } & $0.2010 * * *$ & $0.2181 * * *$ & $0.2020 * * *$ \\
\hline & $(0.0689)$ & $(0.0672)$ & $(0.0645)$ \\
\hline \multirow[t]{2}{*}{ Industry Tech Sophistication } & $0.1336 * * *$ & $0.1278 * * *$ & $0.1284 * * *$ \\
\hline & $(\mathbf{0 . 0 3 1 3})$ & $(0.0307)$ & $(0.0310)$ \\
\hline \multirow[t]{2}{*}{ Firm Marketing Sophistication } & $0.7208 * * *$ & $0.7575 * * *$ & $0.7194 * * *$ \\
\hline & $(0.1723)$ & $(0.1662)$ & $(0.1818)$ \\
\hline \multirow[t]{2}{*}{ Industry Marketing Sophistication } & 0.0045 & 0.0071 & 0.0032 \\
\hline & $(0.0071)$ & $(0.0069)$ & $(0.0071)$ \\
\hline \multirow[t]{2}{*}{ Corruption } & $-0.2923 *$ & $-0.2164 * *$ & $-0.1053 *$ \\
\hline & $(0.1576)$ & $(0.0855)$ & $(0.0612)$ \\
\hline \multirow[t]{2}{*}{ Distance } & -0.1526 & -0.1106 & -0.0428 \\
\hline & $(0.1397)$ & $(0.1470)$ & $(0.1822)$ \\
\hline \multirow[t]{2}{*}{ US firm } & -1.4074 & -1.6835 & 0.6088 \\
\hline & $(1.1931)$ & $(1.4200)$ & $(0.6623)$ \\
\hline \multirow[t]{2}{*}{ US firm * Corruption } & $0.5801 *$ & $0.2993^{*}$ & -0.0392 \\
\hline & $(0.3265)$ & $(0.1831)$ & $(0.1014)$ \\
\hline \multirow[t]{2}{*}{ Rho $(1,2)$} & 0.0601 & 0.0443 & -0.2183 \\
\hline & $(0.1990)$ & $(0.1888)$ & $(0.2467)$ \\
\hline No of obs Eq1 & 5688 & 6320 & 6004 \\
\hline No of obs Eq2 & 345 & 367 & 365 \\
\hline Log L & -1082.00 & -1197.25 & -1194.90 \\
\hline
\end{tabular}

Standard errors are listed in parentheses. ${ }^{* * *},{ }^{* *},{ }^{*}$ denotes significance at $1,5,10 \%$ level, respectively 
APPendix TAble 1A. Summary Statistics

\begin{tabular}{|l|c|c|c|}
\hline \multicolumn{1}{|c|}{ Variable } & No of obs. & Mean & Std. Dev. \\
\hline GDP & 21 & 19,651 & 38,812 \\
GDP per capita & 21 & 1,321 & 1,422 \\
WDR Corruption Index & 18 & 3.7 & 0.7 \\
TI Corruption Index & 20 & 7.6 & 1.2 \\
Neumann Corruption Index & 20 & 4.3 & 1.9 \\
Corporate tax rate & 21 & 29.5 & 6.5 \\
Distance between source and host countries & 7,752 & 5,314 & 3,412 \\
Firm size & 399 & $4,179,212$ & $11,900,000$ \\
Production diversification & 402 & 4.3 & 2.1 \\
Firm Technological Sophistication & 195 & 1.7 & 3.5 \\
Industry Technological Sophistication & 355 & 2.3 & 3.1 \\
Firm Marketing Sophistication & 242 & 1.0 & 0.7 \\
Industry Marketing Sophistication & 364 & 22.8 & 16.4 \\
\hline
\end{tabular}

Note: * refers to "investors" in the sample, i.e., firms that invested in at least one country.

Firm Technological Sophistication $=($ Firm R\&D spending $/$ Net sales $) /($ Average Industry R\&D spending / Net sales)

Industry Technological Sophistication $=$ Average Industry R\&D spending $/$ Net sales

Firm Marketing Sophistication $=($ Firm advertising spending $/$ Net sales $) /($ Average Industry advertising spending / Net sales)

Industry Marketing Sophistication =Average Industry advertising spending / Net sales 
Appendix Table 2A. Corruption Measures

\begin{tabular}{|c|c|c|c|}
\hline & WDR 1997 & TI 1999 & $\begin{array}{c}\text { Neumann } \\
\text { Index }\end{array}$ \\
\hline Albania & & 8.7 & \\
\hline Azerbaijan & 4.6 & 9.3 & 6 \\
\hline Belarus & 4.2 & 7.6 & 4 \\
\hline Bulgaria & 4.6 & 7.7 & 4 \\
\hline Croatia & & 8.3 & 4 \\
\hline Czech Republic & 2.8 & 6.4 & 4 \\
\hline Estonia & 2.2 & 5.3 & 2 \\
\hline Macedonia, FYR & 3.1 & & 8 \\
\hline Georgia & 4.2 & 8.7 & 4 \\
\hline Hungary & 2.6 & 5.8 & 6 \\
\hline Kazakhstan & 4.3 & 8.7 & 4 \\
\hline Latvia & 3.9 & 7.6 & 4 \\
\hline Lithuania & 3.3 & 7.2 & 0 \\
\hline Moldova & 4.2 & 8.4 & \\
\hline Poland & 3.1 & 6.8 & 4 \\
\hline Romania & & 7.7 & 6 \\
\hline Russian Federation & 3.8 & 8.6 & 8 \\
\hline Slovak Republic & 4.1 & 7.3 & 4 \\
\hline Slovenia & & 5.0 & 2 \\
\hline Turkmenistan & & & 4 \\
\hline Ukraine & 3.4 & 8.4 & 4 \\
\hline Uzbekistan & 4.4 & 9.2 & 4 \\
\hline Mean & 3.7 & 7.6 & 4.3 \\
\hline
\end{tabular}

Source: see Appendix I 